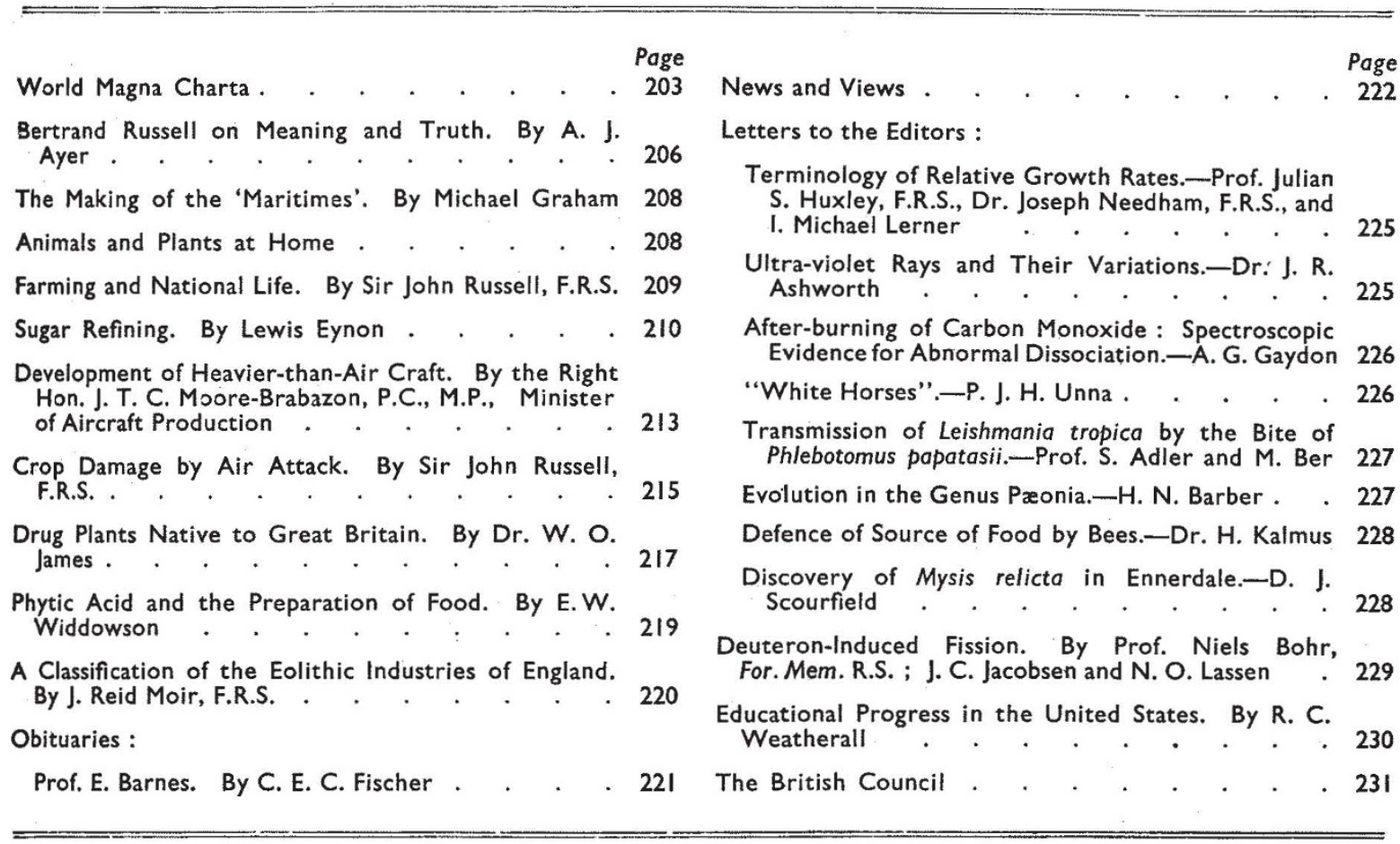

\title{
WORLD MAGNA CHARTA
}

$\mathrm{T}$ HERE could scarcely be higher tribute to the dramatic instinct and imaginative insight which led Mr. Churchill and President Roosevelt to choose the Atlantic for their historic declaration of peace aims than the fact that German commentators have already recognized and sought to minimize the parallel with the Fourteen Points. They at least have seen that this is no mere declaration of peace aims. It is a moral offensive which strikes Germany in one of her fundamental weaknessesthe dread and certainty of impending disaster.

Unsatisfactory as have been some of the recent debates on propaganda or political warfare, and slight the evidence that the Government was really alive to the value of the 'fifth arm' and prepared to integrate it into the general stragegy of the War, this master-stroke of the meeting and Declaration of the Atlantic provides convincing evidence that the important contribution to British defence and British strategy made by the Prime Minister in his speeches and broadcasts is now recognized. As a statement of peace àims, more could not be expected than is contained in the Declaration; less would scarcely have satisfied the bulk of those who were demanding a declaration of peace aims. Much more important, this clear enunciation of principles derived directly from the President's formula of the four freedoms is the starting-point for a moral and political offensive that will lead to the accelerated disintegration of Nazism. 'The peace offensive and initiative have passed into Anglo-American hands.

There have indeed already been welcome signs in recent speeches by Mr. Eden that in the field of political warfare Great Britain is no longer to remain on the defensive. In his speech at Leeds on July 6, Mr. Eden declared emphatically that the Government is not in any circumstances prepared to negotiate with Hitler at any time or on any subject. We would intensify our war effort until he and all he stood for was utterly destroyed. In the House of Commons a month later, on August 6, Mr. Eden reiterated the distinction between the military and the economic treatment of Germany. Every recourse that can be devised must be taken to see that Germany does not for a sixth time plunge Europe into war. There could be no wavering on that point although it would be to our disadvantage and to Europe's disadvantage that Germany should be economically ruined after the War. Mr. Eden went on to indicate that the Government had made certain changes in the work 
for the co-ordination and for the operation of our political warfare, and that we were entering on a period of greater opportunities in this field.

The eight points of the Declaration made by the President of the United States and Mr. Churchill, representing His Majesty's Government in the United Kingdom, are as follows :

First, their countries seek no aggrandizement, territorial or other.

Second, they desire to see no territorial changes that do not accord with the freely expressed wishes of the peoples concerned.

Third, they respect the right of all peoples to choose the form of Government under which they will live ; and they wish to see sovereign rights and self-government restored to those who have been forcibly deprived of them.

Fourth, they will endeavour, with due respect for their existing obligations, to further enjoyment by all States, great or small, victor or vanquished, of access, on equal terms, to the trade and to the raw materials of the world which are needed for their economic prosperity.

Fifth, they desire to bring about the fullest collaboration between all nations in the economic field, with the object of securing for all improved labour standards, economic advancement and social security.

Sixth, after the final destruction of Nazi tyranny, they hope to see established a peace which will aford to all nations the means of dwelling in safety within their own boundaries, and which will afford assurance that all the men in all the lands may live out their lives in freedom from fear and want.

Seventh, such a peace should enable all men to traverse the high seas and oceans without hindrance.

Eighth, they believe all of the nations of the world, for realistic as well as spiritual reasons, must come to the abandonment of the use of force. Since no future peace can be maintained if land, sea, or air armaments continue to be employed by nations which threaten, or may threaten, aggression outside of their frontiers, they believe, pending the establishment of a wider and permanent system of general security, that the disarmament of such nations is essential. They will likewise aid and encourage all other practicable measures which will lighten for peace-loving peoples the crushing burden of armament.

This unequivocal declaration regarding Nazism deals the first blow in the political offensive for which Sebastian Haffner calls in his book "Offensive against Germany". While waging war with all our strength, we are giving it a purpose which makes resistance on the enemy's part superfluous and impossible. The most cursory reading of the Declaration of Mr. Churchill and President Roosevelt, with its reference to the final destruction of Nazi tyranny and the pledge to endeavour, with due respect for existing obligations, to further the enjoyment by all States, great or small, victor or vanquished, of access on equal terms to the trade and raw materials of the world, which are needed for their economic prosperity, indicates how well the opportunity has been grasped.

Here at long last Anglo-American co-operation is fashioning weapons for a moral offensive, perfecting the technique and tactics of effective propaganda. Here is the break with the wavering policy of the last ten years, and the creation of a policy giving full power to propaganda, confronting the misery and slavery of the Nazi New Order with an equally tangible but nobler New Order. Here is the formulation of our cause in terms which should make it an irresistible moral weapon.

No better answer could indeed be given than the Declaration of the Atlantic to Nazi and Fascist attempts to represent the War as a conflict between the large and proper ambitions of young and vigorous races and the unimaginative selfishness of two democracies that have lost the capacity for leadership. The dramatic setting is well calculated to carry the generous spirit of the principles embodied in the Declaration across the frontiers and into the hands of every country that lies under the Nazi yoke. Here is the testimony that Great Britain has accepted the formula of President Roosevelt, that it has turned its back on the world of 1939 and is prepared to make the sacrifices involved in the establishment of the four freedoms and the pursuit of the constructive economic policy by which alone the world can be made free from fear and free from want.

The Declaration does not propose to set up a world in which a man will have a privileged position because he is British or American. On the contrary, in the world contemplated he may be asked to make real sacrifices of national interest or prestige, and from this fact alone the declaration derives immense value, both for the prosecution of the War and for the settlement of the world thereafter. There is nothing in the terms of the documont which has not already figured in the speeches of British and American statesmen. President Roosevelt's great speech upholding the four freedoms is not more pertinent in this connexion than the Prime Minister's refusal even in our darkest hour last summer to abate one jot of our commitments to restore liberty to those peoples who have been deprived of it, or Mr. Eden's recent insistence that peace must not bring destitution even to the guilty. It is the formal recognition of such aims and principles, the assumption by the United States and the British Empire of a joint responsibility for all that is implied in the establishment of such a peace, and the definite association with those aims and principles of the destruction of Nazi oppression and the disarmament of the 
aggressor nations, and the enactment of measures to secure peace and order while leading ultimately to collective disarmament, which give the declaration the force of high explosive in the hands of friends of. liberty in all the oppressed countries.

"Here in Britain," said Mr. Eden, on July 6, "we must lay the foundations of a new Europe, at meetings of the Allied Governments", and the forthcoming meeting will acquire fresh inspiration and value from this demonstration not merely of American association with that task, but also that the Government is imaginatively alive to the possibilities and opportunities of fashioning the future of men's hopes amid the sights and sounds of war. On the wide waters of the Atlantic and this free soil of Britain, the forces of freedom are being marshalled, and the Declaration affords reasonable assurance that the future peace settlement will not fail because it either lacks large and bold economic imagination, or makes too little provision for safeguarding Europe from another outburst of aggression. Not again can Britain and the United States take too lightly their duties of order and peace.

The eight clauses of the Declaration deserve and should receive the closest study. Even at a first glance, their resemblance to principles already enunciated by many responsible studies of the central problem of Germany and European orderas, for example, the conclusions of the recent broadsheet issued by Political and Economic Planning (PE P) on "The Future of Germany"-is as remarkable as the harmony of the whole circumstances in which the Declaration was made with the conditions of a moral offensive, as indicated by Sebastian Haffner, or by Mr. Wickham Steed in recent letters in The Times. The hopes the Declaration will inspire in Europe are well founded, because here at last is clear recognition of the twin and inescapable conditions of any true peacethe provision of real incentives to observe it and real deterrents against breaking it.

It has been clear for months past that both in Great Britain and in the United States it is increasingly recognized that the economic foundations of peace are as important as the political, that vanquished and victors will have to live together in the world of to-morrow, and that a rising standard of living, such as a well-ordered world can furnish, will be one of the indispensable guarantees of security and the permanent answer to the more specious elements of the Nazi and Fascist appeal. That is the fundamental conception which has inspired the work of the LeithRoss Committee, the Willingdon Commission or the agreements in regard to shortages and surpluses concluded last June between the United Kingdom and the Dominions of Australia and New Zealand. Its embodiment in this Declaration, the estab- lishment of freedom from fear and want as a world objective, should give fresh purpose and incentive to all such efforts and movements.

No less emphatic is the fifth clause, affirming the desire to "bring about the fullest collaboration between all nations in the economic field with the object of securing for all improved labour standards, economic advancement, and social security". That affirmation should give fresh heart to the many already concerned in dealing with the technical problems involved, and should lend fresh purpose to the meeting of the International Labour Organisation already contemplated this autumn. The solemn exclusion of arbitrary territorial changes and of territorial and material ambitions from our war aims is reaffirmed, and recognition of the right of all peoples to choose the form of government under which they will live is repeated, as well as the affirmation of our desire to see sovereign rights and self-government restored to those who have been deprived of them.

The means by which these principles are to be translated into practice have still to be worked out, but already much machinery lies to our hand for the task. The Declaration, as already suggested, gives new importance to the meetings of the Allied Governments in London. In that embryonic conception of a free united Europe, of a European cabinet, must be worked out the mechanism by which the choice of form of government for the occupied and enemy territories must be devised, so that the suppression of liberties in one country is never again allowed to threaten the liberties of others. The addition to those meetings of free German representatives from among the many distinguished German émigrés already to be found in Great Britain, parallel with the Free French representatives, might well supply the vital touch, particularly in the formulation of the strategy and tactics of political warfare on the increasingly offensive scale which the Declaration should rightly inspire.

These are but a few of the consequences which should follow from this historic meeting and Declaration. Gratitude to President Roosevelt for suggesting the meeting and to Mr. Churchill for his instant response, and admiration for the dramatic sense and timing of both meeting and Declaration, will not be the less for the further indication it affords of growing Anglo-American co-operation, and of readiness to accept the full responsibilities of world leadership and all that such responsibilities involve. The courage and imagination which have been displayed are the best assurance that the world will not look in vain to Great Britain and America to provide the leadership and resources adequate to establish the world order outlined in this historic Declaration. 